\title{
Concordance between the loss of resistance technique and ultrasound in measuring the distance from the skin to the epidural space in pediatric patients: Observational study
}

\section{Concordancia entre la técnica de pérdida de resistencia y ecografía en la medición de la distancia entre la piel y el espacio epidural en pacientes pediátricos: Estudio observacional}

Piedad Cecilia Echeverry-Marín ${ }^{a}(\mathbb{D})$, Andrea Carolina Pérez-Pradilla ${ }^{a, b}$ (D), Bernardo Reyes-Escobar ${ }^{b}$ (D), Rocío del Pilar Pereira-Ospinac (D) Manuela Quiroga-Carrillo ${ }^{d}$

\author{
${ }^{a}$ National Committee of Pediatric Anesthesia, Sociedad Colombiana de Anestesiología y Reanimación (S.C.A.R.E.). Bogotá, D. C., Colombia \\ ${ }^{b}$ Instituto Roosevelt. Bogotá, D. C., Colombia \\ c Universidad de La Sabana. Chía, Colombia \\ ${ }^{d}$ Education and Research Area, Instituto Roosevelt. Bogotá, D. C., Colombia.
}

Correspondence: Carrera 4 Este \# 17-50, Instituto Roosevelt, Departamento de Educación e Investigación. Bogotá, D. C., Colombia. E-mail: rociopo@unisabana.edu.co

\section{Abstract}

What do we know about this problem?

Studies conducted today have not included Latin American populations; however, due to the differences in body build, it is important to determine whether this correlation is maintained across different populations.

What is the contribution of this study?

New information about the role of ultrasound in determining the distance to the ligamentum flavum and recognizing the proximity of the dura is provided to help avoid accidental puncture of this structure in a Latin American population.

How to cite this article:

Echeverry-Marín PC, Pérez-Pradilla AC, Reyes-Escobar B, Pereira-Ospina RDP, Quiroga-Carrillo $\mathrm{M}$. Concordance between the loss of resistance technique and ultrasound in measuring the distance from the skin to the epidural space in pediatric patients: Observational study. Colombian Journal of Anesthesiology. 2020;48(4):e935.

\section{Introduction}

The use of ultrasound in regional anesthesia has become a standard technique to improve nerve block accuracy and reduce associated complications. The literature reports a good correlation between the distance from the skin to the dura mater or the ligamentum flavum measured on ultrasound and the conventional technique of "loss of resistance". Latin American populations have not been included in the studies conducted so far but, because of differences in physical build, it is important to determine whether this correlation is maintained in the various populations. This paper offers new information about the role of ultrasound in determining the distance to the ligamentum flavum and recognizing the proximity of the dura mater to avoid accidental puncture of this structure in Latin American populations.

\section{Objective}

To determine correlation and concordance in estimating the distance from the skin to the epidural space between the loss of resistance technique and ultrasound measurement.

\section{Methodology}

Observational study conducted in 52 pediatric patients who received general anesthesia plus epidural analgesia for acute perioperative pain management between July 2014 and November 2015 to assess correlation and concordance between loss of resistance and ultrasound measurement of distance to the epidural space.

\section{Results}

There is a correlation between distances measured using the two techniques, which appears to be higher as patient age increases. As for concordance, the study found that $0.43 \mathrm{~cm}$ should be added to the ultrasound measurement to achieve agreement with the distance obtained using the loss of resistance technique; however, the interval between the two measurements is $1.15 \mathrm{~cm}$. 


\section{Conclusions}

A correlation was found between the measurement taken from the skin to the epidural space using ultrasound and the measurement obtained with the traditional needle puncture and loss of resistance technique. Although concordance was not as expected and the distance measured with ultrasound may be smaller than the real measurement with the needle, ultrasound offers good guidance regarding proximity to the epidural space.

\section{Keywords}

Regional anesthesia; pediatrics; epidural space; ultrasonography; safety.

\section{Resumen}

\section{¿Qué sabemos acerca de este} problema?

Los estudios realizados hasta ahora no han incluido población latinoamericana y debido a las diferencias en la contextura física es importante determinar si esta correlación se mantiene en varias poblaciones.

\section{¿Qué aporta este estudio de nuevo?}

Se aporta nueva información sobre la utilidad del ultrasonido para determinar la distancia al ligamento amarillo y advertir la cercanía de la duramadre con el fin de evitar la punción accidental de esta estructura en población latina.

\section{Introducción}

El uso del ultrasonido en la anestesia regional se ha convertido en una técnica estándar para mejorar la precisión de los bloqueos nerviosos y disminuir las complicaciones relacionadas con dicha anestesia. La literatura informa que hay una buena correlación entre la distancia entre la duramadre o el ligamento amarillo y la piel según el ultrasonido y la técnica convencional de "pérdida de resistencia". Los estudios realizados hasta ahora no han incluido población latinoamericana y, debido a las diferencias en la contextura física, es importante determinar si esta correlación se mantiene en varias poblaciones. Con este trabajo se aporta nueva información sobre la utilidad del ultrasonido para determinar la distancia al ligamento amarillo y advertir la cercanía de la duramadre con el fin de evitar la punción accidental de esta estructura en población latina.

\section{Objetivo}

Determinar la correlación y concordancia en la estimación de la distancia de la piel al espacio epidural entre la técnica de pérdida de resistencia y la medición por ultrasonido.

\section{Metodología}

Se llevó a cabo un estudio observacional en 52 pacientes pediátricos, que recibieron anestesia general más analgesia epidural para manejo del dolor agudo perioperatorio entre julio de 2014 y noviembre de 2015 . Se evaluó la correlación y la concordancia de la distancia medida al espacio epidural entre la técnica de pérdida de resistencia y la distancia por ultrasonido.

\section{Resultados}

Existe una correlación entre la distancia obtenida mediante las dos técnicas de medición que parece aumentar a medida que aumenta la edad de los pacientes. En cuanto a la concordancia se encontró que a la medida tomada por ultrasonido se le debería sumar $0,43 \mathrm{~cm}$ para que concuerde con la distancia tomada por pérdida de resistencia; no obstante, el intervalo entre ambas medidas es de $1,15 \mathrm{~cm}$.

\section{Conclusiones}

Encontramos una correlación entre la medida tomada desde la piel hasta el espacio epidural por ultrasonido y la tomada por la técnica tradicional de punción con aguja y pérdida de resistencia. Aunque la concordancia que hallamos no fue la esperada, y la medición del ultrasonido puede ser menor a la medición real encontrada con la aguja, es una buena guía para advertir la cercanía del espacio epidural.

\section{Palabras clave}

Anestesia, regional; pediatría; técnica de pérdida de resistencia; ultrasonido; seguridad.

\section{INTRODUCTION}

Regional anesthesia offers several benefits that are well documented in the literature: lower intra-operative requirement of inhaled and intravenous anesthetics, postoperative analgesia, reduced stress response in children, and faster postoperative rehabilitation and recovery.
However, a failure rate exists and there is a potential risk of complications associated with regional anesthesia, in particular when the techniques are performed blindly and by staff in training. The introduction of the use of ultrasound to guide regional techniques reduces the percentage of failures and the development of complications, something which is particularly evident in the pediatric population (1-3).
Ultrasound-guided techniques, introduced in 1994 by Kapral to guide regional anesthesia (4), have resulted in higher success rates as they help reduce the volume of the anesthetic injected and allow accurate identification of the distance from the skin to the anatomical site where the block is performed; this reduces the incidence of complications due to injuries 
in neighboring structures such as vessels, nerves or membranes. Some studies have found that ultrasound localization of the epidural space in infants and children reduces the time to perform the block as well as the number of complications (5). Regional blocks play an important role in pediatric anesthesia as a means to provide analgesia and reduce the need for anesthetics, resulting in clear benefits for these patients (6-10).

The use of ultrasound has become the gold standard for improving block accuracy and reducing complications related to regional anesthesia $\underline{(11,12)}$. It has been used as an essential tool to guide the needle and measure distances in the neural axis (12-16), particularly in highly complex patients with bone malformations or physical conditions that hinder adequate identification of anatomical landmarks when performing landmark-guided neuroaxial blocks. Ultrasound provides accurate information about the distance from the skin to the ligamentum flavum in children, reducing the risk of accidental dural puncture (5).

Prior studies have examined the distance between the skin and the thoracic epidural space with the loss of resistance technique using $0.9 \%$ saline solution; they measured the distance from the tip of the needle localized in the epidural space (with the traditional loss of resistance technique) to the skin. This distance correlates with age and weight in pediatric patients; hence the equation in centimeters $(\mathrm{cm})$ developed to calculate the approximate distance to the epidural space in children. Two equations using age or weight can be applied to estimate the distance between the skin and the epidural space; numbers in bold are constant in the equations. In the first equation, age is used as follows:

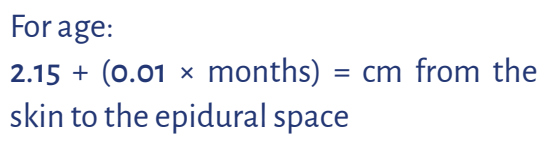

For weight:

$1.95+(0.045 \times \mathrm{kg})=\mathrm{cm}$ from the skin to the epidural space
This showed a correlation with age and weight as parameters to guide thoracic epidural puncture in children (17).

Although new advances in the development and design of medical equipment and devices for children have improved the safety profile of regional anesthesia $(18,19)$, experience and skills are of paramount importance if complications are to be avoided.

Tsui, Tran and other authors have found a good correlation between ultrasound-based measurements of the distance between the skin and the dura or ligamentu flavum, as compared to the conventional loss of resistance technique (20-22). However, there is no accurate agreement given discrepancies between the two determinations due to factors such as needle orientation, tissue deformation under pressure, operator experience with ultrasound, the amount of subcutaneous tissue, pressure on the transducer, among other things $(5,23)$. For these reasons, discrepancy between the two measurements may range between 0.1 and $6.1 \mathrm{~mm}$ in the pediatric population (5).

The traditional formula proposed by Bernard Dalens - in which the epidural space in children is determined by converting weight in kilograms into millimeters from the skin to the epidural space - appears to have a correlate with the patient's weight, size, age and body mass index (BMI); however, these assessments have not been replicated in Latin American patients, whose physical build is very different from that of caucasian patients in whom these types of studies were conducted (24). We decided to conduct a study with the aim of determining correlation and concordance between two techniques for measuring the distance to the epidural space in our pediatric population: an ultrasound-based measurement and a measurement based on the traditional loss of resistance. The hypothesis was that there is no good concordance between the distance to the epidural space measured by ultrasound and the distance measured using of the conventional loss of resistance technique.

\section{METHOD}

An observational study was conducted in 52 pediatric patients between 1 and 18 years of age taken to surgical procedures requiring general anesthesia plus epidural analgesia for the management of acute perioperative pain, between July 2014 and November 2015. Convenience sampling was used and all pediatric patients that met the inclusion criteria consecutively during the study period were selected. Sample size calculation was not made. The relationship between two techniques for measuring the distance to the epidural space was assessed: loss of resistance versus ultrasound guidance. Apart from proving morphological differences between age groups, the aim was to determine concordance in the distance to the epidural space between the two techniques; for this reason, an analysis broken down by age was not conducted and results were expressed in terms of the global population.

The following were the selection criteria to determine patient inclusion in the study: age between 1 and 18 years; American Society of Anesthesiologists (ASA) classification 1, 2; elective surgery; informed consent for regional anesthesia technique and authorization to participate in the study; absence of contraindications for epidural regional block; absence of anatomic deformity preventing the performance of a epidural regional block (scoliosis or prior spine surgery); ability to stand in order to measure height and weight before going into the operating room.

The following were the exclusion criteria: refusal to accept a epidural regional technique by thelegal guardian, considering that the patients were underage; any contraindication for the performance of a epidural block; inability to measure height or weight; ASA classification of 3 or more; previous inclusion in the study (patients could participate in the study only once).

In all patients, general anesthesia induction was done with inhaled 
sevoflurane or intravenous remifentanil plus propofol (if a venous access was in place); the airway was secured and the patient was placed in lateral recumbency to identify the L2-L3 space (longitudinal axis) and to measure the distance between the skin and the posterior complex using ultrasound along the short axis (Sonosite M-turbo, L25x transducer, 13-6 MHz). Distance was recorded in centimeters (Figure 1). Measurement of the distance to the epidural space by ultrasound was done in $100 \%$ of cases by two anesthetists with experience doing ultrasound in children.

After chlorhexidine antisepsis in the puncture site, a 10-cm 18C Touhy needle was used through a median approach to make a perpendicular puncture of the skin at the level of L2-L3 and was advanced until achieving loss of resistance with air; after the space was identified, the needle was marked with a sterile marker, and a metering tape was used to measure the distance, which was recorded in centimeters.

\section{STATISTICAL METHODS}

Univariate descriptive statistics are used for the study variables. Quantitative variables are expressed in quartiles, means and standard deviations, while qualitative variables are used for absolute and relative frequencies.

The method proposed by Bland and Altman in 1986 is used to assess concordance between measurements of the skin-epidural space distance (SED) and ultrasound distance (UD). A brief introduction of this method is found in Kwiecien et al. (25).

Given expected concordance differences among age groups, the BlandAltman analysis was carried out in four groups defined by quartiles of the sample distribution by age. Additionally, the Kruskal-Wallis non-parametric test was used to assess potential differences in the SED and UD variables in the different age groups.

FIGURE 1. Short (transverse) and long (longitudinal) axis ultrasound measurement of the epidural space from the skin .

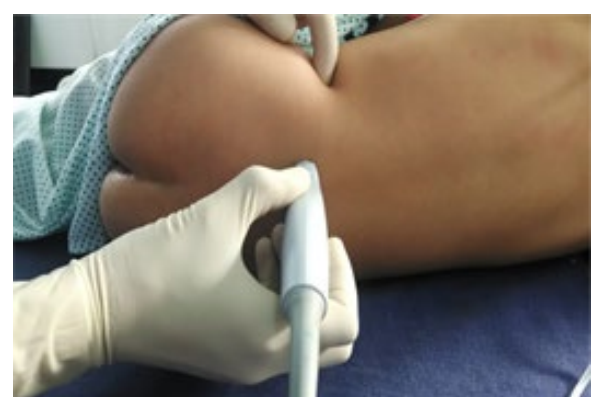

Short axis placement of the transducer.

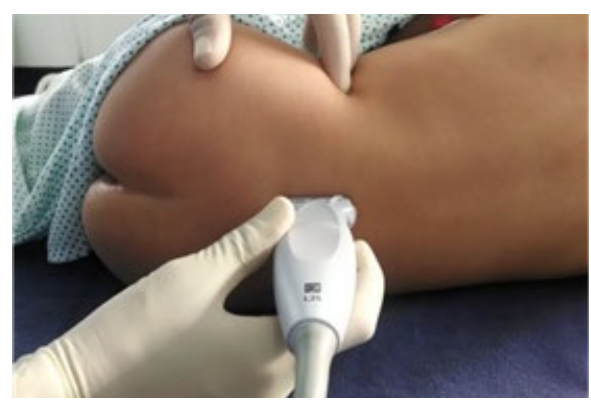

Long axis placement of the transducer.

SOURCE: Authors.

This is considered a risk-free study in accordance with Resolution 8430 of 1993 of the Colombian Ministry of Health, considering that it is a prospective observational research in which no interventions were made. Confidentiality and veracity of the data were guaranteed.

\section{RESULTS}

The analysis included 52 pediatric patients taken to surgical procedures that required general anesthesia plus epidural analgesia for the management of acute perioperative pain, between July 2014 and November 2015. The sample included patients between 1 and 18 years of age, 31 females and 21 males, with a mean age of 8.34 years.

Descriptive statistics for the quantitative variables are shown in Table 1 , and descriptive statistics for age groups broken down by quartiles and gender are shown in

Table 3 shows descriptive statistics for the UD and SED variables for each age

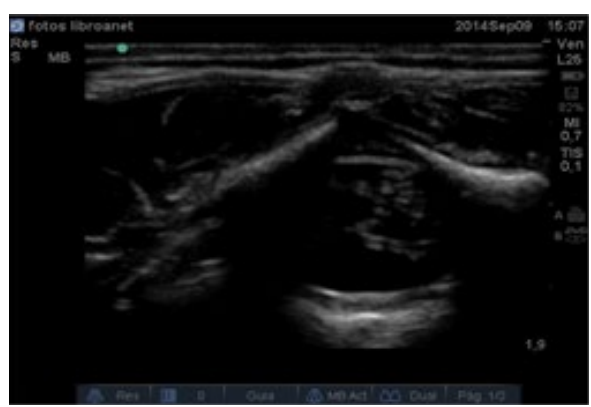

Ultrasound view of the spinal cord on transverse axis.

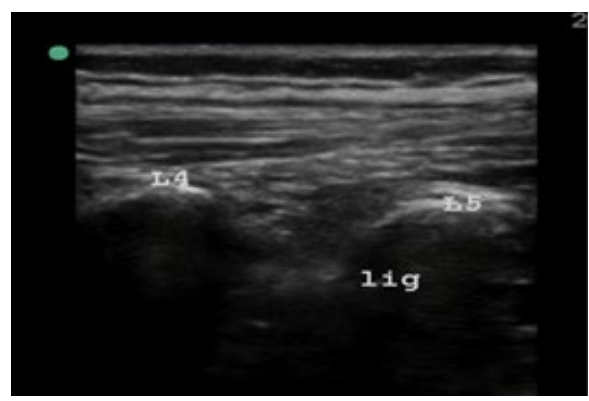

Ultrasound view of vertebrae and spinal cord on the long axis. Lig: posterior complex.

group. Significant differences are observed. Age has an effect on the correlation between the UD and SED variables; as shown in Figure 2 and Table 3, UD and SED increase with age.

This study found low concordance between the two measurements. For the entire population analyzed, $0.43 \mathrm{~cm}$ must be added to the ultrasound measurement in order to reach concordance with the distance measured by loss of resistance. However, it was found that the approximation error for the interval between the two measurements is $1.15 \mathrm{~cm}$. The demographic characteristics are described in Complementary content 1 .

Table 4 shows the Bland-Altman agreement analysis for each age group and biases between the two measurements; the Bland-Altman plots for each age group are shown in Figure 3.

As shown, the highest degree of concordance is found in the age group from 11 to 16 years. For this group, $95 \%$ of the measurements have maximum discrepancies of 1.13 units. It is worth noting that bias for the other age groups is greater, but with narrower limits, as shown in Figure 2. 
TABLE 1. Descriptive statistics for quantitative variables.

\begin{tabular}{|c|c|c|c|c|c|}
\hline Variable & Q1 & Q2 & Q3 & Mean & DS \\
\hline Age & 6 & 8 & 11 & 8.3462 & 3.8137 \\
\hline UD & 1.605 & 2.18 & 3.195 & 2.4996 & 1.0823 \\
\hline SED & 2.1 & 2.85 & 3.725 & 2.9212 & 0.8965 \\
\hline
\end{tabular}

Q1, Q2 and Q3: quartiles, SD: standard deviation, SED: skin-epidural space distance, UD: ultrasound distance.

SOURCE: Authors.

TABLE 2. Gender distribution.

\begin{tabular}{|c|c|c|c|}
\hline Variable & Categories & $n$ & $\%$ \\
\hline Gender & Female & 31 & 59.62 \\
\hline & $(0.6)$ & 20 & 38.46 \\
\hline Age & $(6.8)$ & 9 & 17.31 \\
\hline & $(8.11)$ & 11 & 21.15 \\
\hline & $(11.16)$ & 12 & 23.08 \\
\hline
\end{tabular}

SOURCE: Authors.

TABLA 3. Descriptive statistics for the ultrasound distance and skin-epidural space distance variables for each age group.

\begin{tabular}{|c|c|c|c|c|c|c|c|}
\hline Variable & Age & Q1 & Q2 & Q3 & Mean & SD & p-value \\
\hline \multirow{4}{*}{ UD } & $(0.6)$ & 1.338 & 1.525 & 1.817 & 1.577 & 0.341 & \multirow{4}{*}{$<0.0001$} \\
\hline & $(6.8)$ & 1.925 & 2.16 & 2.438 & 2.21 & 0.501 & \\
\hline & $(8.11)$ & 2.45 & 3.11 & 3.435 & 2.916 & 0.744 & \\
\hline & $(11.16)$ & 3.16 & 3.69 & 4.78 & 3.848 & 0.833 & \\
\hline \multirow{4}{*}{ SED } & $(0.6)$ & 1.8 & 2 & 2.6 & 2.16 & 0.426 & \multirow{4}{*}{$<0.0001$} \\
\hline & $(6.8)$ & 2.1 & 2.6 & 3 & 2.689 & 0.562 & \\
\hline & $(8.11)$ & 3.05 & 3.6 & 3.95 & 3.482 & 0.718 & \\
\hline & (11.16) & 3.7 & 3.85 & 3.975 & 3.85 & 0.601 & \\
\hline
\end{tabular}

$p$ value corresponds to the Kruskal-Wallis non-parametric test. SD: Standard deviation, SED: skin-epidural space distance, UD: ultrasound distance.

SOURCE: Authors.

\section{DISCUSSION}

Pediatric regional anesthesia has gained popularity among anesthetists. Ultrasound use has helped increase the percentage of successful blocks to nearly $100 \%$, and safety in the clinical practice of regional their effectiveness in the management of acute postoperative pain. Almost all neuroaxial anesthesia procedures in children are performed under general anesthesia, thus increasing the success of the block without compromising patient safety (2). However, there is always a risk of complications due to multiple causes associated mainly with the level of experience, the equipment and the type of patient. Although their incidence is low (4.3 in every 100,000 cases), complications of neuroaxial techniques may be serious, as is the case with transient neurological injury (in most cases) or the very rare permanent neurological injury (26). For this reason, ultrasound has been considered a useful guide to identify anatomical structures, recognize sacral foramina, identify the intervertebral space, and arrive at an approximate measurement of the distance to the dura from the skin in each individual patient. Ultrasound guidance has been used in both epidural and caudal blocks in children. Studies have shown good correlation for ultrasound measurements with preserved good reference to guide blocks even as they change with age (27).

This study - the first to be conducted in a pediatric population in Colombia-did not find the expected concordance between two measurement techniques, one with ultrasound from the skin to the dura mater on a transverse axis and the second with the Touhy needle to the point of loss of resistance in the same intervertebral space and performed by the same operator, despite a correlation between the two. As expected, given the technical difficulty both of ultrasound as well as of puncture in younger children, as age increases there is a higher concordance between both measurement techniques.

This analysis shows an overall discrepancy of approximately $0.5 \mathrm{~cm}$ less in the distance measured by ultrasound as compared to the resistance technique, with a variability of $\pm 1.15 \mathrm{~cm}$; this would be explained, among other factors, by the greater pressure applied on the skin with the transducer, leading perhaps to 
underestimations of the distance. Despite the absence of perfect concordance between the two measurements, ultrasound distance could be considered as a guide to prompt the operator to exercise care when nearing that distance and to advance the needle more carefully from that point on. This could prevent accidental dural puncture and offer the operator greater confidence regarding the direction in which the epidural space is located.

TABLE 4. Bias description between the ultrasound distance and skin-epidural space distance measurements for each age group.

\begin{tabular}{|c|c|c|}
\hline Measurement & Value & Age \\
\hline Bias & -0.583 & \multirow{5}{*}{$(0.6)$} \\
\hline \multirow{2}{*}{$95 \% \mathrm{Cl}$ bias } & -0.816 & \\
\hline & -0.35 & \\
\hline \multirow{2}{*}{$95 \%$ LA } & -1.5587 & \\
\hline & 0.3927 & \\
\hline Bias & -0.5525 & \multirow{5}{*}{ (6.8) } \\
\hline \multirow{2}{*}{$95 \% \mathrm{Cl}$ bias } & -0.9944 & \\
\hline & -0.1106 & \\
\hline \multirow{2}{*}{$95 \%$ LA } & -1.5885 & \\
\hline & 0.4835 & \\
\hline Bias & -0.5655 & \multirow{5}{*}{$(8.11)$} \\
\hline \multirow{2}{*}{$95 \% \mathrm{Cl}$ bias } & -0.9019 & \\
\hline & -0.229 & \\
\hline \multirow{2}{*}{$95 \%$ LA } & -1.547 & \\
\hline & 0.4161 & \\
\hline Bias & -0.0017 & \multirow{5}{*}{ (11.16) } \\
\hline \multirow{2}{*}{$95 \% \mathrm{Cl}$ bias } & -0.435 & \\
\hline & -0.435 & \\
\hline \multirow{2}{*}{$95 \%$ LA } & -1.3384 & \\
\hline & 1.3351 & \\
\hline
\end{tabular}

$\mathrm{Cl}$ : Confidence interval, LA: Limits of agreement. SOURCE: Authors.
FICURE 2. Scatter diagram for the ultrasound distance and skin-epidural space distance variables. Lines represent the linear regression model for each group.

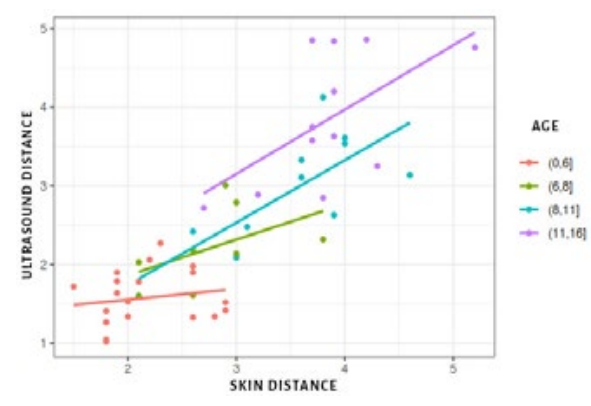

SOURCE: Authors.

This study contributes important elements to the field of regional anesthesia in pediatric patients. Fist, it confirms the correlation reported by other authors $\underline{(26,27)}$ in a group of Latin American children, whose demographic characteristics are very different from those of the populations studied in other parts of the world; and second, the results suggest that measuring distance with ultrasound in

FIGURE 3. Bland-Altman plots for each age group.
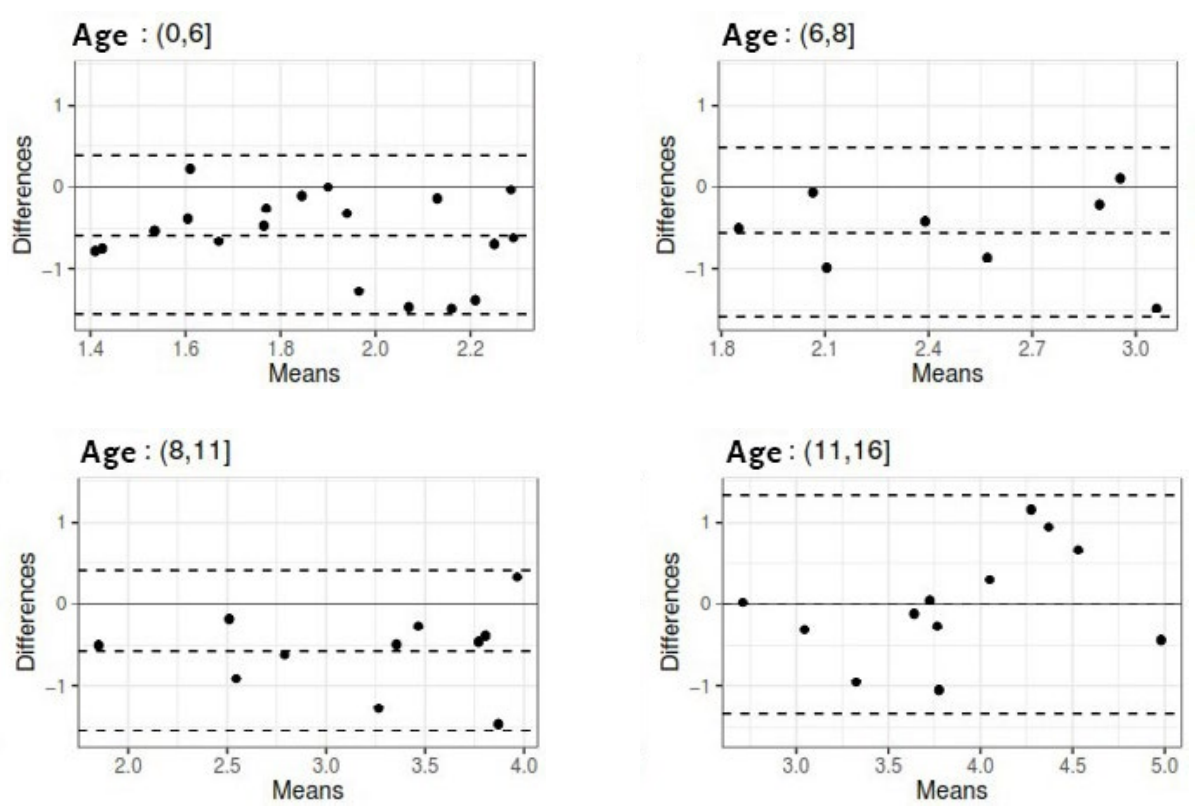

The solid black line marks o or absence of bias. The central dotted line represents bias and the outer dotted lines represent the limits of agreement.

SOURCE: Authors. children over 10 years of age is more useful, a hypothesis that must be corroborated with larger populations; and finally, it reveals a knowledge gap regarding regional anesthesia techniques with sufficient safety margin in children under 5 years of age in whom estimating the space under ultrasound as well as the puncture and application of regional techniques is hindered by morphology.

The heterogeneity of the pediatric patients included in the study within the age range of 1-18 years is considered a limitation of this study. The study was conducted in a relatively small number of patients, resulting in few observations in each age group. Moreover, variability in ultrasound measurements is considered to be operator-dependent and in this study, measurement of the space was done by two anesthetists with experience in pediatrics; concordance of measurements performed by other types of operators with less experience in pediatric patients something which is common in Colombia and Latin America - was not examined. 


\section{CONCLUSIONS}

There is a correlation between the ultrasound measurement from the skin to the epidural space and the measured distance using the loss of resistance technique. Although the concordance found was not as expected and ultrasound measurement appears to be systematically smaller than the distance found with the needle at loss of resistance, ultrasound distance measurement could be used as a guide to warn about the proximity of the epidural space and prompt the operator to exercise caution when making the puncture. According to the observations, ultrasound measurement is a useful technique which improves the safety of regional anesthesia and increases block success, particularly in children over 10 years of age.

Although it is a costly technique and, unfortunately, not available in all settings where regional anesthesia is used, we believe it is useful for neuroaxial blocks in patients with anatomical deformities or in whom anatomical landmarks are difficult to identify.

\section{ETHICAL RESPONSIBILITIES}

\section{Human and animal protection.}

The author declares that no human or animal experiments were carried out as part of this research.

\section{Data confidentiality.}

The authors declare that no data that could lead to the identification of the patients participating in the study appear in this article.

\section{Right to privacy and informed consent.}

The authors declare that no patient data appear in this article.

The study was submitted to the Ethics Committee of Instituto Roosevelt and received approval.

\section{Acknowledgements}

We are grateful to the pediatric orthopedics service and the anesthesia service of Instituto Instituto Roosevelt for their support in allowing the performance of this study within the planned time limit.

\section{Author contributions}

PCEM, ACPP and BRE participated in the development of the protocol and the presentation before the research committee, as well as in patient collection and data tabulation. Authors RPPO and MQC participated in the drafting of the manuscript and the statistical analysis. PCEM and MQC were involved in the final copyediting of the manuscript, statistical data interpretation and final approval.

\section{Funding}

This study was carried out with the authors' own resources.

\section{Conflict of interest}

The authors declare having no conflict of interest and not having received any internal or external sponsorship or funding.

\section{Submissions}

This article is an original academic production carried out at Instituto Roosevelt. It has not been published or presented in any academic event to this date.

\section{REFERENCES}

1. García-Iglesias B, Tielens LKP, Diéguez-García P, López-Álvarez S. Ultrasonografía para anestesia regional en cirugía pediátrica. Cir May Amb. 2007;12(2):55-63.
2. Vieira V, Rodrígues MR, Barretto de Carvalho M do C, Saraiva R. Complicaciones y secuelas neurológicas de la anestesia regional realizada en niños bajo anestesia general. ¿Un problema real o casos esporádicos? Rev Bras Anestesiol. 2006;56(6):382-6. DOI: 10.1590/ So034-70942006000600003

3. Ecoffey C. Pediatric regional anesthesia update. Curr Opin Anaesthesiol. 2007;20:2325. DOI: 10.1016/B978-0-323-03938-3.50139-1

4. Kapral S, Krafft P, Eibenberger K, Fitzgerald $R$, Cosch M, Weinstabl C. Ultrasoundguided supraclavicular approach for regional anesthesia of the brachial plexus. Anesth Analg. 1994;78(3):507-13. DOI: 10.1213/00000539-199403000-00016

5. Kil H, Cho J, Kim W et al. Prepuncture ultrasound-measured distance: an accurate reflection of epidural depth in infants and small children. Reg Anesth Pain Med. 2007:32(2):102-1066. DOI: 10.1016/j. rapm.2006.10.005

6. Harnik E, Hoy G, Potolicchio S, Stewart D, Siegelman R. Spinal anesthesia in premature infants recovering from respiratory distress syndrome. Anesthesiology. 1986;64:95-8. DOI: $\underline{10.1097 / 00000542-198601000-00017}$

7. Spear RM, Deshpande JK, Maxwell LG. Caudal anesthesia in the awake, high-risk infant. Anesthesiology. 1988;69(3):407-9. DOI: 10.1097/00000542-198809000-00021

8. Saint-Maurice C. Indications and limitations or regional anesthesia in pediatric practice. Reg Anesth infants, Child Adolesc. 1995;127-31.

9. Boninsegni R, Salerno R, Giannotti $P$ Andreuccetti T, Busoni P, SantoroS, et al. Effects of surgery and epidural or general anaesthesia on testosterone, 17-hydroxyprogesterone and cortisol plasma levels in prepubertal boys. ] Steroid Biochem. 1983;19(6):1783-7. DOI: 10.1016/0022-4731(83)90360-6

10. Casiani E. Anestesia regional en pediatría: ¿Qué es necesario conocer? Anest México. 2005;17:57-66.

11. Gray AT. Ultrasound-guided regional anesthesia: current state of the art. Anesthesiology. 2006;104(2):368-73, discussion 5A. DOI: 10.1097/00000542200602000-00024

12. Gnaho A, Nguyen V, Villevielle T, Frota M, Marret E, Centili M. Evaluación de la profundidad del espacio subaracnoideo con 
el uso del ultrasonido. Rev Bras Anestesiol. 2012;62(4):1-5. DOI: 10.1590/SO03470942012000400005 .

13. Cork RC, Kryc J], Vaughan RW. Ultrasonic localization of the lumbar epidural space. Anesthesiology. 1980;52(6):513-6.

14. Grau T, Leipold RW, Conradi R, Martin E, Motsch ]. Ultrasound imaging facilitates localization of the epidural space during combined spinal and epidural anesthesia. Reg Anesth Pain Med. 2001;26(1):64-7. DOI: 10.1053/rapm.2001.19633

15. Grau T, Leipold RW, Conradi R, Martin E, Motsch J. Efficacy of ultrasound imaging in obstetric epidural anesthesia. J Clin Anesth. 2002;14(3):169-75. DOI: 10.1016/s09528180(01)00378-6

16. Crau T, Leipold RW, Horter], Conradi R, Martin $E$, Motsch ]. The lumbar epidural space in pregnancy: visualization by ultrasonography. $\mathrm{Br}$ J Anaesth. 2001;86(6):798-804. DOI: $10.1093 / \mathrm{bja} / 86.6 .798$

17. Masir F, Driessen J], Thies KC, Wijnen MH, van Egmond J. Depth of the thoracic epidural space in children. Acta Anaesthesiol Belg. 2006;57(3):271-5.

18. Melman-Szteyn E. Anestesia regional en pediatría... 30 años y más. Rev Mex Anestesiol. 2009;32(1):53-5.

19. Moggi L, Gilmour A, Schkair ]. Anestesia regional en pediatría. Rev Arg Anest. 1997;55(2):87-111.

20. Tsui $\mathrm{BCH}$. New advances in technique for pediatric caudal and epidural placement. Tech Reg Anesth Pain Manag. 2007;11(4):194202. DOI: $10.1053 /$ j.trap.2007.08.002

21. Tran D, Kamani AA, Lessoway VA, Peterson C, Hor KW, Rohling RN. Preinsertion paramedian ultrasound guidance for epidural anesthesia. Anesth Analg. 2009;109(2):661-7. DOI: 10.1213/ane.obo13e3181a94C75

22. Raghunathan K, Schwartz D, Connelly NR. Determining the accuracy of caudal needle placement in children: A comparison of the swoosh test and ultrasonography. Paediatr Anaesth. 2008;18(7):606-12. DOI: 10.1111/j.1460-9592.2008.02529.x.
23. Bauer M, George III J, Seif J, Farag E. Recent advances in epidural analgesia. Anesthesiol Res Pract. 2012;2012:1-14. DOI: 10.1155/2012/309219.

24. Cravero JP, Rice L]. Regional anesthesia in infants, children, and adolescents. Anesth Analg. 1996;83(4):892.

25. Kwiecien R, Kopp-Schneider A, Blettner M. Concordance analysis: part 16 of a series on evaluation of scientific publications. Dtsch Arztebl Int. 2011;108(30):515. DOI: 10.3238/ arztebl.2011.0515

26. Cook TM, Counsell D, Wildsmith JAW. Major complications of central neuraxial block: Report on the Third National Audit Project of the Royal College of Anaesthetists. $\mathrm{Br}$ ] Anaesth. 2009;102(2):179-90. DOI: 10.1093/ bja/aen360

27. Abukawa Y, Hiroki K, Morioka N, Iwakiri $\mathrm{H}$, Fukada $\mathrm{T}$, Higuchi $\mathrm{H}$, et al. Ultrasound versus anatomical landmarks for caudal epidural anesthesia in pediatric patients. BMC Anesthesiol. 2015;15(1):1-4. DOI: 10.1186/ s12871-015-0082-0 


\section{COMPLEMENTARY CONTENT}

\section{Demographic characteristics}

\begin{tabular}{|c|c|c|c|c|c|}
\hline $6-8$ & 6.83 & 22.34 & 1.19 & 15.60 & $\begin{array}{c}1(55.55) \\
2(44.44)\end{array}$ \\
\hline $9-11$ & 10.09 & 35.69 & 1.38 & 18.77 & $\begin{array}{l}1 \text { (54.54) } \\
2(45.45)\end{array}$ \\
\hline $12-16$ & 13.58 & 43.49 & 1.51 & 18.96 & $\begin{array}{l}1(83.33) \\
2(16.66)\end{array}$ \\
\hline
\end{tabular}

ASA: American Society of Anesthesiologists, BMI: Body mass index.

SOURCE. Authors. 